\title{
EASTERN ORTHODOX THEOLOGY
}

\section{INTRODUCTION}

AmONG all the secondary disciplines and auxiliary sciences of Sacred Theology, probably none is so widely neglected as that branch of Comparative Theology which treats of the differences of faith and practice between Catholics and Eastern Orthodox. There are multiple reasons for such neglect, and the neglect has not been very conscious or intentional. Some reasons why this branch has been neglected in the past are: seminary schedules are already very crowded; the theology professors are often burdened with other assignments of teaching, preaching or parochial activities, leaving a minimum of leisure for research in matters not immediately pertinent to their classes; and up to now there has been no treatise in this field written in English-in fact, any depth of research in Oriental Theology will involve the reading of source material in the more recondite tongues such as Modern Greek, Russian and Roumanian.

While it is true that fundamentally the Orthodox are very close to the Catholics and that only a few points of disagreement between them are of importance, yet there is a fairly wide area of discrepancy in view-point, in emphasis, in accidentals that provides material for controversy between the theologians of both churches. A course in all these matters is given by the present writer in Fordham's Russian Institute. It is a thirty-hour course, that is, two hours a week for one semester. It is obvious therefore that in a paper of this kind it will not be possible to do more than give a survey of the points of controversy and go more thoroughly into a few of the most important questions.

In contrasting the differences between Catholic and Orthodox teaching, it is never possible to predicate things absolutely of the Orthodox, because since the time of the schism in 1054, there has been no central authority with real power to impose restrictions on the speculations of theologians in the Orthodox Church. When it is said, therefore, in the course of these remarks that such or such a teaching is that of the Orthodox Church, we mean merely that such is the 
common teaching of the Orthodox theologians. As a matter of fact, on every doctrine that is controverted between the two churches, there is a variety of Orthodox opinion ranging all the way from strict Catholic belief to very modern Protestant thought. But the belief of the majority of the Orthodox clergy and people is the one which will be presented here as the "Orthodox Faith." 1

\section{Transition: Orthodox Symbolic Books; Theologoumena.}

Where do we find this official faith? In controversy with the Orthodox, to which official pronouncements of their church can we appeal in order to know what they teach? On their own admission, they accept the first seven Ecumenical Councils. Whatever has been determined by them is accepted as having equal authority with express statements in Holy Scripture. The teachings of the Fathers of the Church are also held in highest esteem.

Official summations of Orthodox belief are to be found in the documents which they call the "Symbolic Books"- "symbolic" here meaning not figurative, but "pertaining to the faith" (from "Symbolon," the Greek technical term for a creed). A symbolic book is, therefore, eqivalent to a creed, like the Niceno-Constantinopolitan creed used at Mass in both East and West.

The chief symbolic books are the "Confession of Orthodox Faith" of Peter Moghila, Metropolitan of Kiev (1640); the "Orthodox Confession" by Dositheos, Patriarch of Jerusalem (1672); the Catechisms of Philaret Drozhdov, Metropolitan of Moscow (1823) and the Encyclical Letter of Anthimos VII, Patriarch of Constantinople (1895).

There are two well known points on which Catholics and Orthodox agree as against the Protestants: namely, the double Rule of Faith, Scripture and Tradition, and the fact that there are seven Sacraments. These two points, unequivocally stated by the Patriarch Jeremias II

1 This statement that there is strict Catholic belief among some Orthodox on every doctrine will seem like an exaggeration-at least with regard to the Primacy. But even here it is not an exaggeration. The Russian theologian Rosanov, writing about the Petrine texts says: "If these texts mean anything, they mean that the Pope is the head of the Church. But Russia does not acknowledge the Pope. I am a Russian. Therefore I do not acknowledge the Pope." (Vassili Rosanov, "Along the Walls of the Church," St. Petersburg, 1906.) 
of Constantinople, in his reply to the Lutheran theologians of the University of Tübingen in 1576, effectively destroyed Protestant hopes of joining forces with the Orthodox in a union of non-papal churches. These same two points were solemnly read to the assembled delegates at Evanston, Illinois last summer by Archbishop Michael of the Greek Orthodox Church, when he warned the Protestants that Orthodox believers could not compromise their faith for a union of the Churches.

When Orthodox theologians use the term Tradition, they mean not only what we do, but more. The whole manifestation of Christ's life in His Church is called by them the Tradition of the Church. It finds its concrete expression in the decrees of the councils, in the liturgy, in the writings of the Fathers, in the customs and laws, and even in the art of the Church.

Any Christian who departs from this Tradition is a renegade. There is no Pope to define what the Church's tradition is on any point; the body of the faithful retain this living tradition through the enlightenment of the Holy Spirit. Tradition is manifested by Holy Scripture and authoritative ecclesiastical documents such as the Patristic writings and the Symbolic books. We only know what books belong to Scripture because of Tradition. (We agree with this point.) The Orthodox have no sympathy for modern scientific scriptural research: listen to the sacred books read in the liturgy, and listen with love and faith, and the Holy Ghost will tell you what you need to know about their inner meaning. (Here Orthodox thought approaches Protestant private interpretation.)

Everything that is explicitly contained in full living Orthodox Tradition must be believed; everything else ranks simply as a theologoumenon.

Here is an example of how the term theologoumenon was used by the Orthodox on an historic occasion. After the Old Catholic schism, several efforts were made to unite with the Anglicans and with the Orthodox. Finally, a convention of Old Catholic, Anglican and Orthodox theologians took place in St. Petersburg, Russia, in 1892. They agreed very readily on their denial of the Pope's Primacy, but the convention foundered on the subject of the Filioque. The Anglicans and Old Catholics stoutly maintained the Catholic doctrine. 
Finally the Orthodox agreed to let a special committee study the matter to find out if the Filioque doctrine really is de fide or merely a theologoumenon. The committee worked two months and concluded that it was de fide. One member of the commission, a V. V. Bolotov, disagreed, saying that the Holy Ghost's procession from the Father is de fide, but that His Procession from the Father and the Son was only a theologoumenon.

In general, the Russian theologians tend to regard the matter benignly and admit that the Filioque dispute is more a matter of words than real discrepancy in doctrine. The Greeks, however, have never yielded in this matter, and still cite this in all their modern polemical writings, as a sample of how the Roman Church has fallen into heresy. ${ }^{2}$

\section{Doctrines Controverted \\ (1) Lesser Differences}

Some of the secondary issues of controversy between Eastern and Western theologians are: The West's abandonment of Baptism by immersion; the restriction of the priestly administration of Confirmation; the restriction of Extreme Unction only to those in danger of death. Two sacramental matters are of prime importance; the epiclesis question and the condoning of divorce. We shall treat them more thoroughly below.

As far as the Immaculate Conception of the Blessed Virgin Mary is concerned, it is remarkable that in the Eastern Liturgies used by Catholics and Orthodox alike, Our Lady is spoken of repeatedly as the all-pure one, the one completely without stain, the one who is more sublime than the angels themselves. Except for a few Orthodox theologians who misinterpret a text of St. John Damascene in a homily on the Annunciation (PG 94,835), the East in general believed in the Immaculate Conception of Our Lady for eighteen hundred years and with greater consistency than the West--the divergence of opinion arising chiefly in recent times and, one suspects, largely in opposition to the fact that the Pope defined it as a dogma of faith. This last remark is particularly true of some modern Orthodox opposition to Our Lady's Assumption. Pope Pius XII did not define that Our Lady died. The Greek Church traditionally speaks of Our Lady's

${ }^{2}$ Cfr. Gustave Weigel, S.J., "El Cristianismo Oriental," Buenos Aires, 1945. 
"KIMISIS," and the Russians of "USPENIE" - Mary's "falling asleep." But even the most ancient ikons of Mary's falling-asleep show her being taken up, body and soul, into heaven. Over half of all the great cathedrals and abbeys of Russia were dedicated to the Blessed Mother, and the majority of these are under the title of the Assumption. It is hard to escape the conclusion that any Orthodox opposition to the Assumption results only from misapprehension that the Pope declared Our Lady died, and from the fact that the Pope defined the Assumption without consulting the Orthodox.

As far as the Filioque controversy is concerned, Eastern Fathers and Doctors, such as St. Basil the Great, and St. John Chrysostom, employ the formula "ek Patròs dià Huiou (from the Father through the Son) - which certainly amounts to the same teaching as the West's formula "ex Patre Filioque" (from the Father and the Son) - a point which two great Eastern Fathers, St. Maximos and St. Tarasios, so eloquently argued at Constantinople long before the great schism of the eleventh century.

The Filioque controversy concerns not only the dogmatic question of the procession of the Holy Ghost, but also the disciplinary question of adding the word Filioque to the creed. Even those Orthodox who admit our explanation of the dogma, still hold that the West, by adding to the creed, violated the prohibition of the Council of Constantinople in 381 against changing the creed. Catholics answer this objection by saying that the word Filioque clarifies or amplifies the creed, but does not really change the creed by adding something new in doctrine- which is the sense of the Council's prohibition. Orthodox opposition to the Catholic teaching on Purgatory is due to confusion on several points, but chiefly to opposition to the Catholic belief in the fire of Purgatory. But the Reunion Council of Florence in 1438 did not define the existence of fire in Purgatory; it is not therefore de fide, although it is the common teaching of Western theologians. But if the Orthodox maintain that there is no Purgatory, they render meaningless for themselves the beautiful prayers in the Eastern Liturgies said for the repose of the departed souls. ${ }^{3}$

3 The noted Russian litterateur, Miss Helen Iswolsky, testifies that the Russian peasants' traditional expression for the life of the recently departed is a phrase which may be translated as "walking through torments." 
Two Major Disputes in Sacramental Theology

\section{(2) The Epiclesis}

We mentioned before that the epiclesis and divorce are two points of sacramental theology that are still of considerable importance in controversy between the two Churches. Let us now look more closely at these two points.

In the Byzantine Liturgy the "Epiclesis" is the name given to the prayer occurring soon after the Consecration, in which the power of the Holy Ghost is invoked upon the Eucharistic elements. The text reads

Moreover we offer Thee this spiritual and unbloody sacrifice, and we pray and beseech and entreat Thee; send down Thy Holy Spirit upon us and upon these gifts lying before us . . . and make this bread the precious body of Thy Christ. Amen.

And that which is in this chalice the precious Blood of Thy Christ. Amen. Having changed them by Thy Holy Spirit. Amen. amen, amen.

So that for those who receive them in Communion, they may serve as a cleansing for the soul, for the forgiveness of their sins, as a communication of the Holy Ghost and a full participation in the Kingdom of heaven, and to promote their confidence in Thee - and let them not serve for the judgment or condemnation of any
who receive them.

The question about the true meaning of the Epiclesis was first treated as a matter of controversy by Nicholas Cabasilas in the fourteenth century in his "Exposition of the Sacred Liturgy" (MG-150,425 ), and this was followed up by Simon Thessalonicensis in his "Exposition on the Divine Temple" (MG-155,729).

At the Council of Florence (1438) the matter was discussed, and all the Greeks, except Mark of Ephesus and Isidore of Kiev, admitted that it was the words of consecration (or "Institution") which effected the transubstantiation. Mark of Ephesus claimed that the words of Institution and the Epiclesis were equally important and necessary. Older Orthodox theologians follow him. Some modern Orthodox theologians, such as Androutsos and Dyobouniotes, say that 
only the Epiclesis effects the consecration. Most Slav authors hold that both the Consecration and the Epiclesis are necessary.

Let us examine the arguments adduced by Orthodox theologians from the days of Nicholas Cabasilas until now. They say that the operation of each sacrament should be effected by an invocatory prayer. In the Mass it is done by invoking the Holy Ghost. The Catholic theologians admit the operation of the Holy Ghost in all the sacraments, but deny that it has to be explicitly invoked in order to achieve the effect of the sacrament.

Cabasilas maintains that the words of institution are not the apt form for the sacrament because they are not joined by the sign of the Cross. Catholics say that the Eucharist is a unique sacrament by Christ's very institution. It is a sacrifice as well as a sacrament; it not only gives grace but contains the very Author of grace. Hence, it is not necessary that it parallel the other sacramental rites completely. However, the bread and wine are blessed with the sign of the cross just before the words are said.

Cabasilas says that even the Latins, in practice, have an Epiclesis in their Mass, namely, in the prayer "Supplices te rogamus" after the Consecration. Simeon of Thessalonica says the Latins have an Epiclesis, but before the Consecration, namely, in the prayer "Quam oblationem." Latin liturgists admit that there is some reason to look upon these prayers as being Epicleses, but only in an obscure way.

Cabasilas says that in the Liturgy of St. Basil, the sacred gifts are called antitypa, i. e., species, after the Consecration and just before the Epiclesis proper. Catholics reply that this word antitypa employed by St. Basil does not prove the saint did not yet consider the gifts consecrated, because the word is used by Greek Fathers even when there can be no doubt from the context that the real Body and Blood are meant; e. g., St. Cyril of Jerusalem (MG 33,1124) says: "Those who taste are not bidden to taste bread and wine, but the species (antitypon) of the Body and Blood of Christ." After the Epiclesis proper, St. Basil's Liturgy prays that "all we who become partakers of this one bread and chalice may be united, etc." Does this prove that even after the Epiclesis St. Basil denies the Real Presence just because he does not say "body and blood" instead of "bread and chalice"? Certainly not! 
The Orthodox adduce St. John Damascene as support for their theory because he speaks of the importance and necessity of the Epiclesis. St. Thomas Aquinas, commenting on this point, declares (In IV Sentent., I, IV, dist. VIII quaest II, art. 3, ad I am): "The operation of the Holy Ghost as principal agent does not exclude the instrumental power of the Savior's words."

However, even if St. John Damascene's words cannot be explained by St. Thomas' distinction, then it is still possible to concede that on this point the great Damascene erred. Moreover, we should like to match St. John Damascene's assertion with the lucid declaration of another great Eastern Doctor, St. John Chrysostom, who most clearly teaches that the words of institution effect the change (MG 49,380): "The priest stands and says, 'This is my body.' This saying (rhema) transforms what lies before him."

Again, the very fact that the oldest codices of the Byzantine Liturgy prescribe a deep bow from the clergy after the words of institution, and the fact of the solemnity with which the words are sung aloud and are answered with "Amen" by the people, are proof that the ancients really considered the Consecration as the moment when the transubstantiation took place. Moreover in the Coptic and Ethiopian Rites, the people not only sing "Amen" after the words of Consecration, but add phrases like "This is now indeed true; this we firmly
believe," etc.

What then is the true sense of the Epiclesis prayer? How do Catholics explain it?

There are two accepted theories. The first is that of Cardinal Bessarion, who declares that what happens at the moment of the Consecration is something so stupendous that the Liturgy can view it only in parts and can appreciate it only be degrees. Since all the activities of the Blessed Trinity outside itself are the results of the cooperation of all three Persons, the Consecration in the Liturgy is also the work of all three Persons. Now the Liturgy stresses the work of the Father before the Consecration, (in the Preface), the work of the Son during the Consecration, (in the account of the Institution), the work of the Holy Ghost after the Consecration (in the Epiclesis). It happens in other sacraments too, e. g., Baptism and Extreme Unction, that the prayers said after the "form" ask for the graces already 
given in the sacrament that was just conferred when matter and form were united.

There is a similar transfer of the time element in the dramatic anticipation found in the Roman Rite at the Offertory of the Mass, when the unconsecrated bread and wine, in view of what they are to become, are already referred to as "this pure, unspotted offering"; and when, over the same unconsecrated bread and wine, the priest prays: "we offer this chalice that brings us salvation"; "accept this oblation which we are offering in memory of the Passion, Resurrection and Ascension of our Lord. ..."

Another such transfer of time is present in the dramatic hindsight occurring in the Roman Rite at the Offertory-Antiphon of a Requiem Mass, when petitions are offered for the departed souls regarding matters already settled by God in the Particular Judgment: "deliver the souls of all the faithful departed from the pains of hell." Obviously the Church is here envisioning an operation of God's mercy which has already taken place because of God's foreknowledge that this prayer was going to be said. By the time the Requiem Mass is offered for the departed souls, they have already been judged and cannot be helped if they are in hell.

The second Catholic explanation of the Epiclesis, and the one favored at the Council of Florence, looks upon the prayer as a petition for the fruits of Communion-that these consecrated elements be made the instruments of grace for us when we receive them. Hence the upholders of this theory say that the essential sense of the prayer is found in the second part where we read: "So that for those who receive them in Communion, they may serve as a cleansing for the soul, for the forgiveness of their sins, etc. . . " Hence, the Holy Ghost's beneficent operation is invoked so that the fruits of Holy Communion may come to us.

Both these explanations have much to commend them and each of them serves to highlight very interesting truths about the Liturgy.

\section{(B) Divorce}

Among the points of sacramental theology disputed between theologians of the Catholic and of the Orthodox churches, certainly there is none of more practical importance than that of divorce. The 
Catholic Church, from the days of the Apostles down to the present moment, has held steadfastly to the sacred dictum of our Lord (Mark 10:9): "What God hath joined together, let no man put asunder." Among the Orthodox, however, a gradual toleration of divorce has been growing. The seeds were planted by the caesaropapism of the Emperor Justinian who inserted into his great Code of Laws in 542 some license for divorce in case of adultery. By the end of the ninth century the abuse was already well established. At the present time the remarriage of divorced people in the Orthodox churches constitutes the greatest single practical hindrance to reunion of the churches.

How do the Orthodox theologians justify their toleration of divorce? They cite the words of Our Lord in the Gospel of St. Matthew (19:9): "I say to you that whoever puts away his wife except for immorality (Orthodox adultery) and marries another, commits adultery; and he who marries a woman who has been put away commits adultery."

The Orthodox claim that these words justify divorce because of adultery. They also claim that although a valid marriage endures until the death of one of the parties, there are certain circumstances that can arise when a condition tantamount to death exists between a husband and wife, and that this "moral" death, therefore, dissolves the bond, just as certainly as does physical death. Such conditions, for example, would be a serious disease contracted by one of the parties, an absence of one party for five years (sometimes three years), the crime of one party's bringing infamy on the other, the exile of one as a punishment (for example, to Siberia), or other special cases to be judged by the patriarch on their individual merits.

It is interesting to note that although practice in the East has been lax, it has sometimes been reprobated by Church authorities. Eastern theologians too, have admitted on occasion that the practice is an abuse. The great Russian canonist, N. Souvorov, in his "Manual of Church Law" (St. Petersburgh, 1912) admits that the Orthodox practice is not that of early tradition, when he writes: "The Roman Catholic Church has held firmly to the severe rule of the discipline of the early ages: conjugal union is broken only by the death of one of the parties." 
It is significant that among the numerous picayune instances of Eastern fault-finding with Western practice, the intransigence of the Roman Church on the matter of divorce is never mentioned by polemicists who profess to be horrified at the fact that Western clerics shave and that we discontinue the Alleluia during Lent! What torrents of abuse would they not have poured on the West, if they were themselves convinced that divorce was according to the mind of Christ or according to the tradition of the Apostles!

Since, however, the text cited above from St. Matthew does pose a problem for explanation, it will be useful to study it and see why ancient tradition and constant Catholic interpretation do not admit that it endorses divorce.

The first law of Sacred Scripture's interpretation demands that we put together all the related texts; truth cannot contradict itself. We must also study the text in the light of its context.

In the nineteenth chapter of St. Matthew's Gospel, we find the Pharisees asking our Lord whether it was lawful to put away one's wife for any motive at all. Both the great rabbinical schools of our Lord's time held that divorce was licit for the Jews, but they disagreed on the reasons necessary, the school of Shammai holding that only adultery was just cause, while the school of Hillel taught that any physical or moral defect in one's wife was cause enough.

Our Lord does not bother to settle their argument, but proceeds merely to show that any divorce is contrary to primitive revelation by appealing to the teachings of the first chapters of Genesis: "Have you not read that the Creator, from the beginning, made them male and female, and said, 'For this cause a man shall leave his father and mother and cleave to his wife, and the two shall become one flesh?' Therefore, now they are no longer two, but one flesh. What therefore God has joined together, let no man put asunder."

The Pharisees could not deny this clear determination of God's original will, and indeed they taught that marriage was indissoluble for all men except the Jews, for whom there was a privilege. Since our Lord's answer made no mention of their "privilege," they asked why Moses had allowed divorce? Christ answers that it was a concession God granted out of His great condescension, because of the hardness of their hearts, that is, because of their constant resistance to 
God's will. But he makes it clear that this was not God's original plan when he instituted marriage. Then He goes on to say. "And I say to you whoever puts away his wife, except for immorality, and marries another, commits adultery, and he who marries a woman who has been put away, commits adultery."

Some Protestants and the Orthodox say that Christ here allows divorce for adultery. But to admit this is to accuse our Lord of contradicting Himself, for $\mathrm{He}$ has just declared that God from the beginning made marriage indissoluble and intended that to remain the pattern. Moreover, in citing the teaching of our Lord on this point, neither St. Mark (10:11-12) nor St. Luke (16:18) make mention of the exception-phrase. And the great St. Paul, in his first Epistle to the Corinthians (7:10-11), says he is reporting what the Lord Himself teaches, namely, that if spouses separate, there is to be no remarriage.

What then is the meaning of the phrase in St. Matthew "except for immorality"? Catholic exegetes traditionally taught that the phrase "except for immorality" referred to the first part of the statement, namely, it gives the reason for the separation of the spouses, but did not give a reason for remarriage. The parallel texts of Sacred Scripture, and the inability of our Lord, Eternal Truth, to contradict Himself, justified this interpretation.

However, within the past hundred years, the great progress made in scientific Scripture studies, especially in the field of linguistics, has thrown a completely new light on this text. The Greek word used for "immorality" is "porneía." Father Joseph Bonsirven, S.J., a great scholar of rabbinical literature, has shown in his work "Le Divorce dans le Nouveau Testament" (Paris, 1948) that porneia really means concubinage, or a marriage that was invalid according to Jewish laws. Hence, our Lord would be saying "Whoever puts away his wife (except in the case of a spurious marriage) and marries another. ..."

In his first Epistle to the Corinthians (5:1), St. Paul speaks of the man who married his stepmother, a marriage reprobated by God in Leviticus (18:8) and, therefore, considered illicit and invalid by the Jews. The word St. Paul uses here to refer to the spurious marriage is "porneía."

In the Acts of the Apostles we read that the Gentile Christians 
were asked to observe only a few ritual points of the Jewish law, so that the hoped-for fusion of both elements in the new Christian communities might not be impeded. The Gentiles were asked to abstain from idol-offerings, from blood, from strangled meats, and from "porneía." According to ordinary Christian morality they were forbidden to indulge in sins of the flesh: why then speak here of porneia - unless that term means marriage within the degrees forbidden by God to the Jews?

In the Epistle to the Hebrews (12:16), Esau is called immoral (pornos) even though in Genesis we find no mention made of his being guilty of any sexual sins, though we do read that he married Hethite women. Such a marriage outside of Jewry was considered illicit and invalid by the Jews.

In the light therefore of these Scriptural arguments, the text in St. Matthew becomes very clear, and the whole basis for the Orthodox stand in favor of divorce is destroyed.

\section{(3) The Roman Primacy}

Certainly the Primacy of the Pope is the essential point of difference between the Catholic and Orthodox Churches. The arguments most frequently adduced by the Orthodox today are the same as those used by the Protestants; in fact, the Orthodox lean heavily on Protestant sources for this part of their teaching.

You will say, "How can they deny for example, the sense of the great Petrine text, 'Thou art Peter and upon this rock I will build my Church,' etc?"

Great Lutheran authorities like Dr. Heinrich Holtzmann of the University of Strasbourg admit that if the text is genuine at all, then it certainly means what Catholics say it means. But he denies the authenticity of the text. Some Orthodox agree with him. Others content themselves with parroting the explanation of Martin Luther:

Luther said the words "on this rock I will build my Church" mean "on faith like yours I will build my Church."

Regarding the significant words of the Petrine text in St. Luke's Gospel; "et tu, aliquando conversus, confirma fratres tuos," the Orthodox say it means that once St. Peter has been reconverted to 
the Lord after his lapse on Holy Thursday night, he will confirm his brethren by giving a good example of loyalty to the Lord.

Regarding our Lord's constituting St. Peter the head of the Church in charge of both the lambs and the sheep of the flock, the Orthodox claim that our Lord is simply reinstating St. Peter as an apostle in good standing after the triple denial. Yet listen to what one Orthodox theologian says about such a dodge:

"The words of Christ, 'feed my lambs, feed my sheep' contain the whole doctrine of the papacy-which follows as a corollary from them. Our theologians do not know how to explain them, except to keep repeating like parrots 'all the apostles are equal; no one is greater than the others.' That is why the Bishop of Rome is only equal to the Bishop of Kaluga! ${ }^{4}$ How such arguments are repugnant to our Russian honesty!" (Vassili Rosanov, "Along the Walls of the Church," St. Petersburg, 1906.)

So much for the Petrine texts.

Regarding the historical arguments about the use of the Primacy by St. Peter's successors, we must distinguish two periods. After the fourth century there are too many instances of the exercise of papal power to ignore them. Hence the Orthodox polemicists join the Protestants in saying that this exercise of papal authority after the fourth century merely goes to show the overweening lust for power on the part of the bishops of Rome, and that the papal actions represent a complete usurpation of authority.

Regarding the historical arguments we adduce from the first three centuries, showing instances of the exercise of the primacy, we find the Orthodox naming each instance either an accident of history, or an example of how an individual bishop interfered in the affairs of some other diocese. Thus they ignore a point that Catholic theologians stress, namely, that the argument for papal Primacy is a cumulative argument: that the consistency of the papal exercise of universal jurisdiction shows a definite pattern; and that it is exercised by popes who were personally holy men and not proud autocrats. If each instance of the exercise of papal jurisdiction were considered by itself, apart from all other instances, of course it would be possible to say that the example adduced is just an accident

${ }^{4} \mathrm{Kaluga}$ is a small suburban town near Moscow. 
of history or an act of Roman interference. But this is far from being the case.

The Orthodox explanations also ignore the fact that those over whom the popes exercised their jurisdiction either accepted it as the proper thing, or at least did not gainsay it. Moreover, the positive testimonials of great bishops like Saints Ignatius of Antioch, Irenaeus of Lyons and Cyprian of Carthage support the doctrine of the Roman See's primacy, quite apart from any particular instance of its use.

The Orthodox position also completely ignores the explicit teaching of the great Eastern fathers like St. Cyril of Jerusalem, ${ }^{5}$ St. Cyril of Alexandria, ${ }^{6}$ St. Gregory of Nyssa, ${ }^{7}$ St. John Chrysostom ${ }^{8}$ and St. Theodore. ${ }^{9}$ These fathers all say that the Pope is the head of the universal Church because he is the heir to St. Peter's Primacy.

You are all familiar with the renowned letter written to Pope St. Leo by the Patriarchs Maximos of Antioch, Anatolius of Constantinople and Juvenal of Jerusalem after the Council of Chalcedon held in 451 under the presidency of his legates. Among other things, the Eastern Patriarchs clearly recognized the Pope's primacy, saying:

"You have indeed preserved the faith, which has come down to us like a golden stream flowing at the command of our divine teacher. Constituted, as you are, the interpreter of the words of the Blessed Peter for all mankind, you have poured forth upon the universe the blessings he elicited by his faith. Hence we have looked to you as to the leader of our religion to our great advantage.

"You indeed, as the head among the members, presided here in the person of your representatives, who led the way by their correct counsel."

You will ask: "What do Orthodox theologians say about this clear testimony of the Church-Fathers at Chalcedon?" A group of Orthodox theologians were asked this question recently by a Catholic priest and they replied: "The expressions used by the Fathers

$5 \mathrm{PG}, 33,694$.

6 PG, 72, 423.

7 PG, 46, 734.

8 PG, 59, 478; 48, 931; 49, 308; 48, 652 .

${ }^{9} \mathrm{PG}, 99,1152 ; 99,1332$. 
at Chalcedon are nothing more than Oriental imagery and flattery."

If such is the case, then how can we ever be sure just when an Eastern Father is stating something dogmatically correct and when he is indulging in "Oriental imagery"? For example, does St. John Chrysostom really think Our Lady is holier than the angels, or is he merely using Eastern flattery when he sings so beautifully: "Higher in honor than the Cherubim and more glorious beyond compare than the Seraphim, who without harm to thy virginity didst give birth to the Word of God: thee we extol, true Mother of God!" 10

\section{(4) The Church of Christ}

The definition of the Church given by Catholic theologians is the following:

The Catholic Church is the body of believers in Christ which was instituted by our Lord; these believers form a society whose purpose is eternal salvation; they are united by profession of the same faith, by use of the same sacraments and under the rule of their legitimate pastors, especially the Supreme Pontiff.

All the phrases of that definition are important; the Church is called a body of believers to emphasize the fact that the Church is a visible organization - a thing so strenuously denied by the Jehovah Witnesses today, and denied four centuries ago by John Calvin and his followers. Calvin claimed that the Church was made up of those souls predestined by God for heaven; only God knew, therefore, who belonged to His Church.

These heretics forget Our Lord's parable about the grain of mustard-seed that is an image of the Church: (Mt. 13, 31) it is indeed a tiny seed, but when it grows up, it reaches the proportions of a tree in whose branches the "birds of the air," i. e. birds from all sides, take up their dwelling. (In Palestine and other Mediterranean countries, the mustard plant grows to the height of a tree; it is not the mere weed known to farmers of our country.) So too the Church of God, from its small beginnings in Palestine nineteen

10 Commemoration of Our Lady after the Consecration in the Liturgy of St. John Chrysostom. 
centuries ago, would grow and expand until it reached the proportions of a universal haven for souls-its members coming from the "four corners" of the earth. This image is surely that of a visible organization.

Moreover, when Our Lord commissioned the Apostles to go into the whole world teaching and baptizing all nations, $\mathrm{He}$ also said the new converts were to be taught to observe all that $\mathrm{He}$ had commanded (Mt. 28, 20). But Christ commanded the faithful to obey the Apostles as they obey Him: "He who hears you hears Me." And St. Paul exhorted the Church leaders of the Province of Asia, telling them that the Holy Ghost had placed them in positions "to rule over the Church of God" (Acts 20, 28). Human beings do not rule over invisible organizations. Nor does one rule over human beings that are not organized into a group or society with laws to bind them together.

Catholics also stress the fact that the Church must be the one founded by Our Lord. When a so-called church comes into existence only in the fifth century, like that of the Nestorians or that of the Monophysites or in the sixteenth century, like that of the Lutherans or the Calvinists, or in the eighteenth century, like the Methodists', or in the nineteenth century, like the Christian Scientists', it cannot claim very believably to be the Church founded by Christ.

Members of the true Church must also profess the same faith. It is futile to say that those who believe, for example, that Christ is God can be members of the same society of believers as those who say that $\mathrm{He}$ was not God, but only a great man. True members of the Church must also make use of the same seven sacraments instituted by Christ. But some people calling themselves Christians believe there are only two sacraments, others one; others deny that there are any!

Most Eastern Orthodox Christians would agree with the full classical Catholic definition of the Church until they reach the last phrase-under the rule of the Supreme Pontiff. They substitute phrases like "under the rule of the Holy Ghost," or, "of the bishops," or "of Christ and the bishops."

Traditionally the Orthodox have held the Catholic definition 
minus the Pope. But in the last century a whole group of theologians and philosophers among the Russians, called the "Slavophiles," have begun to expound new theories about the Church. What their teaching amounts to is this: they lean to the old error of a chiefly invisible church, a church devoid of any perfect external organization. It seems as if the Slavophile doctrine was expressly excogitated to explain away the lamentable lack of organization in the Orthodox churches today.

Phrases such as the following constantly recur: "in Christ's Church there is nothing juridical," "nothing organizational;" "the Church is an internal union of love and grace;" "liberty and harmony join the true believers," etc.

Alexius Khomiakoff (1860) is one of the banner-bearers of Slavophilism. He was a devout layman and a philosopher. He and the other Slavophiles, like Karsavin, Lebedev, Berdiajev, Kiriyevsky, all glorify the Russian Orthodox church above all others. Vladimir Soloviev, a great Russian philosopher who became a Catholic, points out the fact that the doctrine of the Slavophiles is based on German and French subjective philosophy and really has nothing truly Slav about it!

Khomiakoff nowhere gives a definition of the Church, but his admirers, Karsavin and Berdiajev, formed one from their master's works: "The Church is an intimate and spontaneous synthesis of unity and liberty in love." "Intimate" means the Church is internal and invisible and "spontaneous" means there is nothing juridical about it.

The impression one gets from reading any of these poetically phrased but logically confused elucubrations is this: these philosophers have set about dreaming up a scheme for a Church which would suit their own fancies, instead of starting out-as true theologians and scientific investigators must - with the question "What did Our Lord actually say about His Church?" Scientific honesty does not allow us to figure out a theory and then permit us to twist the words of Christ to fit it; all logic rather demands that we start with the words of Christ, the source, and from them deduce the theory. The Slavophiles lamentably fail to start out by investigating all Our Lord's statements and parables about the kingdom of God and the kingdom 
of heaven, as well as the other inspired records of the visible and organized Church found delineated in the Acts of the Apostles and in the Epistles, especially St. Paul's.

There are some favorite words that the Slavophiles use; one of these is "Juridicism." They claim that the Catholic Church is guilty of three forms of juridicism, namely, secularism (by which church government is "reduced" to the same modes as civil government); exaggeration, (by which law is made the whole basis of unity); arbitrariness, (by which the powers and rights of the individual bishops are limited by the Pope).

In answer to this, Catholics point to the constantly worsening condition of the Orthodox churches, as schisms multiply among them, and no central authority appears to curb the vagaries of doctrine and abuses of practice among them. Somewhat grudgingly, the Orthodox admit that the Catholics have perfect organization, but they decry it. Lebedev, for example, in his book "On the Supremacy of the Pope" (1903, St. Petersburg) says:

The Latin Church has indeed a very strong and perfect organization. It is built like a pyramid. It is an absolute and monolithic monarchy. But is this absolute unity proper to the Church of Christ? Unhesitatingly we reply: not at all, not at all!

Slavophiles believe that all the life and qualities of the Church are communicated to each individual member, including infallibility. This possession of everything by everybody they call "Sobornost." Hence they say the word "katholikos" in Greek is to be derived not from "kath'holen" (meaning "over the whole earth") as Catholics say, but from "kath'holon" (meaning "according to each individual member")!

Khomiakoff says that the Eastern Orthodox Church lives a "life of love" built on grace and sobornost, while all the Western Christians lead a "life of rationalism," the Protestants by relying on their own private judgment, and the Catholics by relying on the judgment of the Pope. He also says that the internal life of the Church (grace) is opposed to the external (juridical) life. Catholics hold that both are necessary and that they complement one another. The Slavophiles by their insistence upon Sobornost and the im- 
portance of each individual member of the Church, seem to destroy the concept of the hierarchy. Soloviev says the Slavophiles want a perfect Church, but by undermining the Pope's supremacy they deprive the Church of the means to attain it-namely, a head and government for the body.

Father George Florovsky, a prominent modern Orthodox theologian, has written a book called "The Church of God" (London, 1934). In it he stresses the concept of the Church as the Mystical Body of Christ and denies Soloviev's charge. He says that in the Mystical Body each member has his part to play, and the bishops have their part. But Catholics reply that by admitting Sobornost, the Orthodox deny the practical importance and authority of the hierarchy. How can the bishops in turn be united without a visible head?

Orthodox theologians of this century are very much concerned with the doctrine of the Mystical Body. Akvilonov says that the doctrine of the Church of Christ is fully contained in the single concept of the Mystical Body of Christ. Lebedev claimed that forgetfulness of this doctrine of the Mystical Body caused the Latins to overlook the truth that Christ is the head of the Church. But Lebedev is very wrong in this regard; St. Thomas and St. Bonaventure treat this doctrine too, as did St. Augustine. And it was discussed at the Council of Florence in 1438. It is true that Latin manuals of theology did not, for years, devote much space to it. But that was because the West had to battle the errors of Protestantism regarding the invisible nature of the Church. In modern times, because of the stress of social consciousness, the truths about the Mystical Body are more thoroughly treated by Catholic authors, and the finest treatment of the doctrine to appear so far is Pope Pius XII's encyclical "Mystici Coporis." The Orthodox refuse to accept the clear Catholic distinction between Christ as the invisible Head of the Church and the Pope, His Vicar on earth, as the visible Head of the Church. They say simply that there cannot be two heads.

Orthodox insistence on the invisible aspect of the Church fits in with the traditional Eastern exaggeration of passivity-leaving everything up to God. Thus they say that, if there are errors or abuses or problems in the Church, the Holy Ghost will inspire the remedy for them. If God wants new believers added to His Church, 
He will accomplish that without the activity and labors of missionaries. If one monk leads a perfect life in the monastery as a contemplative, he gives more glory to God than any number of active but imperfect missionaries, and so on.

It is astonishing that the Orthodox theologians should overlook the fact that Christ-as the all-knowing God-would foresee the difficulties His followers would encounter if they did not have a visible head, and hence would give them a head in St. Peter and his successors. It is surprising, too, that serious Orthodox teachers, in defending the passivity of their Church, should lose sight of the fact that Christ commissioned the apostles to go into the whole world and preach the Gospel to every creature. He surely meant those words not only for the twelve apostles personally but for their successors as well, because He added the words "And behold I am with you all days, even to the consummation of the world." But the apostles were not going to live until the end of the world; the Lord expressly foretold persecution and death for them.

A basic error in all this Slavophile thinking seems to be the denial of true secondary causality. Our Lord's death, for example, won salvation for all men, together with merits and graces sufficient to save many worlds besides our own. And yet He tells His followers that they must suffer too for their salvation: "If any man wishes to be my disciple, let him take up his cross daily and follow me" (Lk. 9,23 ). And St. Paul sums up the mystery in that classic phrase in the Epistle to the Philippians: "Work out your salvation with fear and trembling" (Phlp. 2,13).

Regarding the Church's Magisterium, there is found among Orthodox theologians the error condemned by Pope St. Pius X in his decree "Lamentabili" against the errors of the modernists: "In defining truths the teaching and the learning Church so collaborate that the teaching Church has nothing more to do than sanction the common opinions of the learning Church." 11

Orthodox confusion about the ordinary and universal magisterium of the Church follows from their doctrine of "Sobornost," or the communication of full infallibility to each of the faithful. Hence the Orthodox do not accept our distinction of active and passive infalli-

11 Denziger-Umberg, "Enchiridion Symbolorum," No. 2006, Barcelona, 1946. 
bility, nor that of the Ecclesia Discens and the Ecclesia Docens. When the bishops in a Council define a doctrine, they are not imposing a definition on the faithful, but merely giving expression to the belief of the Church. The hierarchy does not know the faith any better than the faithful; infallibility resides equally in the faithful and in the bishops; infallibility is the prerogative of no individual, but of the whole Church-hence individual popes and bishops can be and have been in error. Any opinion or definition not accepted by the whole Church, both hierarchy and people, is erroneous, say the Orthodox, and it is for this reason that the Councils of Lyons and of Florence enjoy no authority in the East: they were not popularly accepted.

A natural result of this glorification of the faithful by Sobornost is the relative frequency with which one meets the phenomenon of lay theologians among the Orthodox.

Since the bishops are the voice of the Church's tradition, through formulation of beliefs, they should meet in a General Council to give such expression to the truth. There is great variety of opinion on how the Council should be convened. Some say only the bishops need agree about it. Others say it is the business equally of bishops, clergy and people. Some say it is up to the civil power to convene it, though the bishops could suggest it to the civil authorities. Some say every bishop in the world must approve a decision, and not only those present at the council. Some say it would be enough if one Orthodox church, e. g., that of Greece, could secure in writing the approval of every bishop on some proposed point to be defined. Then it could be defined, but it would then become infallible truth only if all the faithful accepted it and confirmed it! How these various plans could ever be reduced to actuality does not seem to preoccupy the Orthodox writers.

Some Orthodox say that the convening of a General Council is impossible without the attendance of the Roman Catholic bishops. But this is at present impossible.

An Orthodox theologian was recently asked by a Catholic: "What answer can an Orthodox bishop give to one of his subjects who asks for a decision on a modern problem?" He replied: "We should seek the answer in the Church's Tradition, especially in the writings of the 
Fathers. The Holy Ghost will tell the bishop what to say if a question arises that really needs an answer."

\section{ConClusion}

Some Orthodox are sincerely concerned about the division of Christendom and about the constant schisms taking place within their own ranks. They join Christians of good will everywhere in praying for unity. Other Orthodox are quite unconcerned about Christian and especially Orthodox disunity. They say external and juridical unity is unnecessary as long as there is the internal unity of love and faith and grace!

The educational level of Orthodox clergy in many places has fallen very low, so that if a man can read well enough to perform the Church's rituals he can be ordained. This is a matter of worry to some Orthodox authorities, who are trying hard to remedy the situation. But the establishment and administration of good seminaries calls for constancy of a missionary character. This type of effort, this activity, has long been foreign to Oriental Christianity's character of passivity. They claim that the important thing is the Liturgy; if the rites are performed, the means of grace are available and that suffices for the faithful. In the meantime the people become more and more ignorant of their religion, as the lack of sermons and instructions leaves their minds unnourished.

Yet there remains very much piety among the Orthodox faithful, due to the grace of the sacraments and the retention of a valid priesthood. We must remember that the vast majority of the Orthodox laity and clergy are in good faith. They have never studied the Petrine texts nor the historical arguments for the Primacy. Simple Orthodox folk have repeatedly said they believe Catholics and Orthodox really belong equally to Christ's Church, and that the present external divisions are just due to disagreements among the bishops. "The 'higher-ups,' like the bishops, are only human and they fight among themselves like the rest of men. But that's none of our business." Statements like these are often heard by our priests who talk with Orthodox faithful. Sometimes the Orthodox faithful, without asking anyone's permission, frequent Catholic churches for Mass and the sacraments, tranquilly believing it makes no difference. 
Because there have been historic precedents for it, there is good reason to hope for the reunion of the Bulgarians, Roumanians, and Ukrainians. The situation is by no means hopeless regarding the Russians; but there seems to be least promise of success working with the Greeks. And yet, God may change the whole situation over night. The least we can do is to pray for unity and realize that the Orthodox are not Protestants. We can be very friendly with their clergy without ever compromising our own Catholic faith and practice.

As long as the Orthodox retain valid orders and continue their tender devotion to the Blessed Mother of God, there is never reason to be despondent about the ultimate fulfillment of our Lord's prayer that there may be "but one flock and one shepherd." (Jno. 10,16).

\section{BIBLIOGRAPHY}

Algermissen-Grundner, Christian Denominations, St. Louis, 1953. Fourth Printing.

Gordillo, Compendium Theologiae Orientalis, Rome, 1950. Third Edition.

Jugie, Le Schisme Byzantin, Paris, 1941.

Jugie, Theologia Dogmatica Christianorum Orientalium ab Ecclesia

Catholica Dissidentium, Paris, 1926-1935.

Ladomerszky, Theologia Orientalis, Rome, 1953.

Weigel, El Cristianismo Oriental, Buenos Aires, 1945.

Clement C. Englert, C.SS.R.

\section{Digest of THE Discussion}

Father McAvoy, Fordham, asked Father Englert to explain the meaning of the Epiclesis and outline the nature of the controversy. Father Englert briefly summed up the treatment of the Epiclesis which occurs fully in his paper and which he had not been able to read because of the time limit.

Father Hennessey of Steubenville: Are Orthodox students studying in Protestant seminaries? Is the practice widespread?

Father Englert: Some of them are doing so. The Orthodox have very few seminaries. Occasionally the Orthodox bishops of Eastern 
Europe send talented young men to universities in Western Europe where they follow the Protestant theology course. Some few Orthodox students are studying in Catholic seminaries in France.

I am unable to say whether or not the practice is widespread, but I do know that in some cases the Orthodox have been driven into the arms of the Protestants-- chiefly the Anglicans-by Catholic coldness to their overtures of friendship.

I have in mind a particular instance. When returning from Europe in 1939, I had as a shipmate a young man, an American-born Roumanian Orthodox student for the priesthood. We became very friendly. When we landed in New York he promised to write to me and did so. I received an invitation to his wedding (in Cleveland, Ohio) and a few months later to his ordination. Of course I could not attend these functions.

Several months later I received a letter from him saying that he had been made a pastor in a large Eastern city and was appalled at the ignorance of religion that he found among his young people. $\mathrm{He}$ wished to remedy the situation by publishing a simple text in English and asked me to suggest sources. I told him to buy the Catholic catechisms. Later he wrote to tell me he had done so, and had copied almost everything except the chapter on the primacy.

Then I received several letters complaining about the fact that in the large city where his parish was located, he could not find any Catholic priest who would be friendly with him. He said he repeatedly approached Catholic priests in a desire to discuss religious matters and in every case was given a cold shoulder and quick brushoff as soon as the Catholic priest discovered that he was an Orthodox priest.

Then the letters stopped. Last year I met him for the first time since our original encounter. He embraced me very affectionately, inquired about my health, and then blurted out immediately- "Of course, Father, remember that I am not a candidate for conversion!"

What caused such an attitude? I found out that he had since fallen a prey to the hearty friendship of the Protestants, who were happy to fill the place of counsellor that no Catholic priest would undertake! Fathers, I do not doubt that a very probable candidate 
for conversion to the Catholic Church was lost by the uncharitableness of our priests in this case.

A similar difficulty exists regarding Orthodox students entering Catholic schools. I am happy to say that four Roumanian Orthodox young men were attending classes with me in Rome at the Pontifical Oriental Institute. But I also know that an American bishop refused the request of a young Greek Orthodox priest who had not had a full education and wanted to take the college courses-as a day student -in a Catholic seminary. I can sympathize with the Bishop's fear that news of such a concession would be spread abroad and probably be distorted-causing suspicion and trouble for him. And I can imagine the consternation of most of our seminaries' superiors if they were to receive such a request. But frankly-should we keep putting off facing up to the problem and continuing to drive friendly Orthodox into the Protestant camp?

Father Bowen of New York: Orthodox clergy and people living in Eastern Europe, as you said, are hardly acquainted with theological difficulties - for example, the question of the Pope's primacy. However, when they reach Western Europe, as you said, they encounter Catholicism for the first time and are impressed by it. What would be the reaction of Orthodox to Catholic life in America?

Father Englert: It would be hard to say, but I declare unhesitatingly that most of the clergy are friendly to us, though this is notably less true of the Greeks than of the other nationalities.

The Greeks seem to lose no opportunity to oppose the Catholics officially. Here are instances: When movie-magnate Skouras built his great Greek Orthodox Church on the West Coast, the brochure published for its dedication gave a brief history of the Orthodox Church. The history went out of its way to say that the Orthodox preserve the ancient faith of Christianity free from the errors of Roman Catholics on the Procession of the Holy Ghost, Purgatory and the Primacy of the Pope.

Another instance of Greek antipathy: I know a Catholic priest of Greek descent who is very kind and friendly to the Greek Orthodox people he meets. Last year a few Orthodox boys of his acquaintance went to Boston to start studies for the priesthood. When they came home on vacation they visited him but almost immediately after 
greeting him, launched into an attack on Catholic doctrine, asking "When are you Catholics going to give up your heresy on the Filioque?" Evidently, if they did not learn any manners at their seminary nor any positive doctrine, they did at least learn to consider Catholics as heretics!

Russian priests are usually friendly to Catholics.

Many Orthodox people, without consulting anyone about it, go to Mass, make their confessions and receive Holy Communion in Catholic churches. As these are usually older people, it does not come to a priest's notice because they ask for no ministration such as baptism or marriage.

Recently such an Orthodox woman was discovered frequenting a Catholic church. A young Catholic priest-with possibly mistaken zeal-told her she could not do that. "Do you mean to say Jesus is not the same in Catholic Communion as $\mathrm{He}$ is in Orthodox Communion? Isn't the Mass the same sacrifice in Greek or in Latin? I am a baptized Christian, so why can't I receive Jesus where I want to?"

Father Maguire of Washington: Are Orthodox sacraments to be regarded as valid?

Father Englert: The Holy See has repeatedly declared that they are. We need be doubtful, however, if there is a case of someone coming from Russia since the Revolution because some of the schisms there among the Orthodox formed groups without bishops and so valid orders were lost.

Father Maguire: In some dioceses conditional rebaptism is practiced. Do you think there is sufficient care exercised in Orthodox baptisms to give a presumption of validity? Does this requirement of rebaptism cause bad feeling with the Orthodox?

Father Englert: There is certainly sufficient certitude about Orthodox baptisms. The Orthodox are very careful about performing the ecclesiastical rites properly. Though the majority of the clergy and people are poorly educated in religious matters, they are attached to the external forms with great devotion and tolerate no deviation from tradition.

Those who are better educated certainly resent any attempts at rebaptism by Catholics. 
But the fact that most Orthodox young people are poorly informed about their religion can be used to advantage by Catholic priests when there is question of a mixed marriage. When, for example, a Catholic girl comes to the rectory and says she wants to marry an Orthodox boy, it would be worthwhile to interview the boy at once, with a view to finding out what he knows about religion. Chances are that he will know very little and could easily be persuaded to become a Catholic. Certainly the effort should be made, and I think you should tell the young men in our seminaries about this.

The fact that the clergy are often poorly educated should make us patient with them. Sometimes our priests ask me impatiently: "How can you say that most of the Orthodox are in good faith? How can they deny the Petrine texts?"

My answer is that they never studied the Petrine texts. They were brought up to believe that Christ is the head of the Church and that His representatives on earth are the bishops. The Pope doesn't enter into their picture except as Patriarch of the West. I wonder how many of our own priests in similar circumstances, if left to themselves to discover the Petrine texts from their own study of the Gospels, would learn to establish the Primacy. Many Orthodox simply have never heard of the arguments for the Primacy, whether from Scripture or from history.

Alfred Sieradski, C.SS.R. Esopus, N. Y. 